Nama : Yulinda Anggrainy Eka Putri

NIM : 312020147

Fakultas : Fakultas Hukum

Tugas : Analisis Jurnal

\title{
A.IDENTITAS JURNAL
}

1.Nama Jurnal : Hanifiya: Jurnal Studi Agama Agama

2.Volume $: 3$

3.Nomor $\quad: 1$

4.Halaman $\quad: 14-26$

5.Tahun Terbit : 2020

6.Judul Jurnal : Ritual Mistis di Dunia Politik: Studi pada Ritual Ngalab Berkah di Gunung Kemukus

7.Nama Penerbit : Fibry Jati Nugroho

\section{B.ISI JURNAL}

\section{Masalah Penelitian}

Ritual mistis masih sangat kental di dalam kehidupan masyarakat. Meskipun zaman telah modern, namun ritual di alam gaib tetap dilakukan. Kehidupan masyarakat tidak dapat dilepaskan dari ritual mistis, yang kemudian di wujudkan dalam laku spiritualnya. Dalam penelitian ini disajikan ritual mistis yang dilakukan oleh para peziarah yang Ngalab Berkah di Gunung Kemungkus. Ritual Ngalab Berkah akan dijadikan sebagai objek kajian dalam kaitannya dengan kontestasi di dunia politik. Dengan menggunakan pendekatan kualitatif dan analisis deskriptif, ditemukan bahwa frame mistis tetap laris dikalangan kontestasi politik. Hasil dari ritual mistis yang berupa Ngalab Berkah di Gunung Kemukus, menjadikan pemimpin, mendapat pulung (kebegjan), serta mendapatkan hukmat dan belas kasihan dari Pangeran Samudra. Ritual mistis yang dijalankan oleh para peziarah terbukti 
sebagai jalan yang cukup ampuh untuk ditempuh para kontestan politik dalam memenangkan kontestansinya di dunia politik.

\section{Lokasi Penelitian}

Obyek Wisata Religi Gunung Kemukus.

\section{Metode Penelitian}

Dalam penelitian ini digunakan pendekatan kualitatif dengan metode deskriptif analisis. Menurut Sugiyono, penelitian Deskriptif merupakan penelitian yang dilakukan untuk mengetahui nilai variable mandiri, baik satu variable atau lebih (independen) tanpa membuat perbandingan atau dengan menghubungkan antara variable yang satu dengan variable yang lainnya. Jenis metode ini digunakan untuk menyajikan data secara menyeluruh dan mendalam terkait dengan interprestasi symbol symbol dan obyek penelitian di dalam masyarakat (Sugiyono, 2012). Obyek kajian dalam penelitian ini meliputi ritual mistis di Obyek Wisata Religi Gunung Kemukus, khususnya dalam kaitannya dengan yang kontestasi di dunia politik. Data dikumpulkan berupa data kualitatif, berupa hasil observasi, hasil wawancara dan juga dokumentasi terkait ritual di obyek penelitian. Adapun narasumber yang akan diwawancarai meliputi Dinas Pariwisata sebagai pengelola Obyek Wisata,Juru Kunci, Peziarah dan Penduduk setempat. Data yang diperoleh kemudian akan di analisis menggunakan analisis deskriptif.

4.Teori yang dipakai Menggunakan teori deduktif. Teori deduktif/pendekatan deduktif adalah suatu prosedur atau cara yang berpangkal pada peristiwa umum, yang kebenarannya itu telah diketahui dan pada akhirnya akan mendapatkan suatu kesimpulan atau juga mendapatkan pengetahuan yang bersifat khusus.

\section{Hasil Penelitian}

Secara factual,ritual mistis masih diyakini dan dilakukan masyarakat di era modern. Di era kontestasi politik, ritual mistis jadi laris dilakukan oleh peserta kontestasi politik. Gunung kemukus salah satu yang laris didatangi untuk ritual menjelang pesta demokrasi. Paradigma 
agama tradisional, dalam hal ini agama jawa yang menjadi pemandu dalam melakukan ritual tersebut. Para peserta kontestasi politik ini meyakini bahwa melalui ritual mistis mereka mendapatkan harmonisasi antara mokrokosmo dan mikrokosmo, kharisma sebagai pemimpin, mendapat pulung (kebegjan), serta mendapatkan hikmat dan belas kasihan dari Pangeran Samudra. Ritual mistis tersebut dipercaya dapat efektif sebagai jalan untuk memenangi kontestasi di dunia politik.

\section{C.KELEBIHAN DAN KEKURANGAN}

\section{Kelebihan}

-Menggunakan bahasa yang mudah dipahami.

-Berisikan pembahasan yang bersifat umum sehingga dari berbagai kalangan bisa memahami.

-Berasal dari sumber yang terpercaya.

-Metode penelitian yang mudah dipahami.

-Isi sesuai dengan judul.

-Mengandung unsur kebudayaan, keagamaa dan kepercayaan.

\section{Kekurangan}

-Halaman yang tidak lengkap sehingga kurang dalam pemahaman lengkapnya. 